\title{
Short Term Effects of Dexamethasone on Histological Structure of Adrenal Gland and Testis of Male Mouse
}

\author{
1,2 Amal I. El-Refaiy
}

${ }^{1}$ Dept. of Biological \& Environmental Science, Faculty of Home Economic, Al-Azhar Univ., Egypt.
$\frac{{ }^{2} \text { Biology Department, The University College in Khafji-Hafr Al-Batin University, KSA }}{\text { Received: } 20 \text { Sept. } 2019 \text { / Accepted } 30 \text { Oct. / Publication date: } 30 \text { Dec. } 2019}$

\begin{abstract}
The purpose of the present study is to investigate the effect of corticosteroids hormone on the adrenal gland and testis of albino mouse. The study was carried out on 30 male mice; the animals were divided into three groups (10 animals per each): group (I) served as control; group (II) treated with $4 \mathrm{mg} / \mathrm{kg}$.bw dexamethasone for 14 days; group (III) treated with $8 \mathrm{mg} / \mathrm{kg}$.bw for 14 days. Histologically, the cortex of adrenal gland revealed obvious clear fibrotic areas, nuclear pyknosis and karyorrhexis in three zones. Testicular sections showed detached, sloughed or vacuolated seminiferous tubules, the majority of seminiferous tubules exhibited necrotic spermatogonia and pyknotic nuclei.
\end{abstract}

Keywords: corticosteroids, Dexamethasone, Adrenal gland,Testis.

\section{Introduction}

Glucocorticoids are the major steroid hormones secreted by the adrenal gland. In therapeutic concentrations, Glucocorticoids are strongly immunosuppressive and anti-inflammatory, which has made them one of the most frequently prescribed, drugs worldwide (Julia, 2006). Unfortunately, they cause numerous side effects on various body systems. Side effects from glucocorticoids are mostly seen with oral and injectable glucocorticoids, but can be seen with inhaled and topical steroids at higher doses (Wahbah et al., 2010). Increased risks of infection, osteoporosis, fracture, gastrointestinal bleeding, and many other pathologies have been reported as common and severe side effects (Kusuda et al., 2019).

Glucocorticoids mediate their effects through a specific intracellular receptors present in almost all cell types including exocrine pancreatic tissues. So the glucocorticoids can induce cell maturation, cell differentiation or even cell death. Also, glucocorticoids had dual effects on exocrine pancreas so that glucocorticoids in appropriate doses have a stimulating effect upon the acinar cell function, whereas large doses of these drugs reduce the exocrine tissue secretory function and affecting its protein-synthesizing capacity (Noel, 2012). Hydrocortisone has the same chemical structure as cortisol and thus most closely resembles the human adrenal hormone (Rabee et al., 2014).

Several studies had been carried out to investigate the severity of adverse effects of hydrocortisone as a synthetic glucocorticoid drug on different body organs such as the pancreas (Gloor et al., 2001), reproductive aspects of female rats (Piffer and Pereira, 2004), the thymus (Rodrigues- Mascarenhas et al., 2006), the liver (Gevorgyan et al., 2008), the hypothalamohypophyseal-adrenocortical system (Yarushkina, 2008) and the hippocampus (Tata and Anderson, 2010).

Dexamethasone is potent synthetic member of glucocotricoids class of steroid drugs. It acts as anti-inflammatory and immunosuppressant. It is 20 to 30 times more potent than the naturally occurring hormone cortisol (Ghadhban and Jawad 2013). It significantly reduced specific physical problems in prostate cancer patients and improved their emotional state (Kornblith et al., 2001), it is used for the treatment of severe liver failure (Harry et al., 2003). Previous studies have shown that elevation of glucocorticoid concentration precedes a decline in testosterone concentration (Sapolsky et al., 2000; Hardy et al., 2005).

Dexamethasone induced spermatogenesis defects including epithelial vacuolizations, sloughing of germ cells, reduction of seminiferous tubule diameter, reduction in the number of sperm heads and

Corresponding Author: Amal I. El-Refaiy, Dept. of Biological \& Environmental Science, Faculty of Home Economic, Al-Azhar Univ., Egypt and Biology Department, The University College in Khafji-Hafr Al-Batin University, KSA. 
significant maturation arrest. (Khorsandi et al., 2013). Furthermore, corticosteroid treatment affects systematic metabolism and decreases the body and organ weights of the liver, thymus, and spleen (Urbach et al., 2002).Another study reported that dexamethasone decreased [Ca2+] and consequently inhibited $\mathrm{Cl}-$ secretion in human bronchial epithelial cells (Kusuda et al., 2019). The present study aimed to investigate the effect of dexamethasone on Adrenal gland, and testis of adult male mice histologically.

\section{Material and methods:}

\section{Experimental animals:}

30 adult male mice weighing $22 \pm 3 \mathrm{~g}$ were used in the present investigation and were supplied from Experimental Animal Unit, Helwan, Egypt. Mice were housed in standard laboratory cages, and given pellet rodent diet and water ad-libitum. They were acclimatized for 5 days before used and maintained under the same laboratory conditions of temperature and natural dark-light cycle.

\section{Drug used:}

Dexamethasone Sodium Phosphate was produced at the Egyptian International Company for Pharmaceutical Industries (EIPICO) with 2 doses equivalent to 4 and $8 \mathrm{mg} / \mathrm{kg} . b . w t$.

\section{Experimental design}

Mice were randomly divided into three groups (10 mice/ group). The first group served as control, while the second and third groups injected muscularly with dexamethasone in doses $(4 \& 8$ $\mathrm{mg} / \mathrm{kg}$. b.wt.) daily for 15 days.

Adrenal gland and testis samples were carefully removed, cut testis into small pieces, fixed in $10 \%$ buffered formalin and processed to get sections of $5 \mu \mathrm{m}$ thick. Sections were stained with Harris haematoxylin and eosin (H\&E) for histological study (Delafield, 1984).

\section{Results}

The control sections of adrenal gland showed a normal histologically features (cortex and inner layer medulla). The cortex contains paranchymal cells and subdivided into zona glomerulosa, zona fasciolata and zona reticularis respectively (Fig. 1). Zona glomerulosa is formed of pyramidal or columnar cells with basal oval nuclei arranged in glomeruli-like structure, which are separated by delicate trabeculae extending from the capsule. Zona fasciculata is composed of polyhedral or cuboidal cells with central vesicular nuclei arranged in one or two cell thick in long radial cords or fasciculae and they are separated by narrowed blood capillaries (Fig. 2). Zona reticularis characterized by an irregular anastomosing network of intermingled cords separated by numerous wide blood sinusoids lined with endothelial cells (Fig 3).

Adrenal gland in animals of group II which injected with dexamethasone $(4 \mathrm{mg} / \mathrm{kg} . \mathrm{bw}$.) revealed obvious clear fibrotic areas in zona glomerulosa, while nuclear pyknosis and karyorrhexis are frequently observed in three zones (Figs. 4\&5). Group III which injected with dexamethasone $(8 \mathrm{mg} / \mathrm{kg} . \mathrm{bw})$ induced degenerative changes involve shrinkage in the thickness of the three cortical zones according to the compression in their cells. An obviously clear cytoplasmic degeneration, Pyknosis, fibrotic areas, dilatation and congestion of blood vessels are observed (Figs.6,7\& 8).

The histological observations on testis of control group have normal seminiferous tubules, spermatogenic cells and interstitial cells (Fig.9).The mice of group II injected with $4 \mathrm{mg}$ dexamethasone showed many histopathological changes; the interstitial tissues between seminiferous tubules are infiltrated and the Leydig cells have pyknotic nuclei (Fig. 10). These alterations became more prominent in the testis cross sections of mice injected with $8 \mathrm{mg} / \mathrm{kg} . b w .(F i g .11)$. In addition to that, dexamethasone induced a pronounced alteration of spermatogenic process with dramatically reductions of spermatozoa produced, dilatation and congestion of blood vessels (Fig 12). 


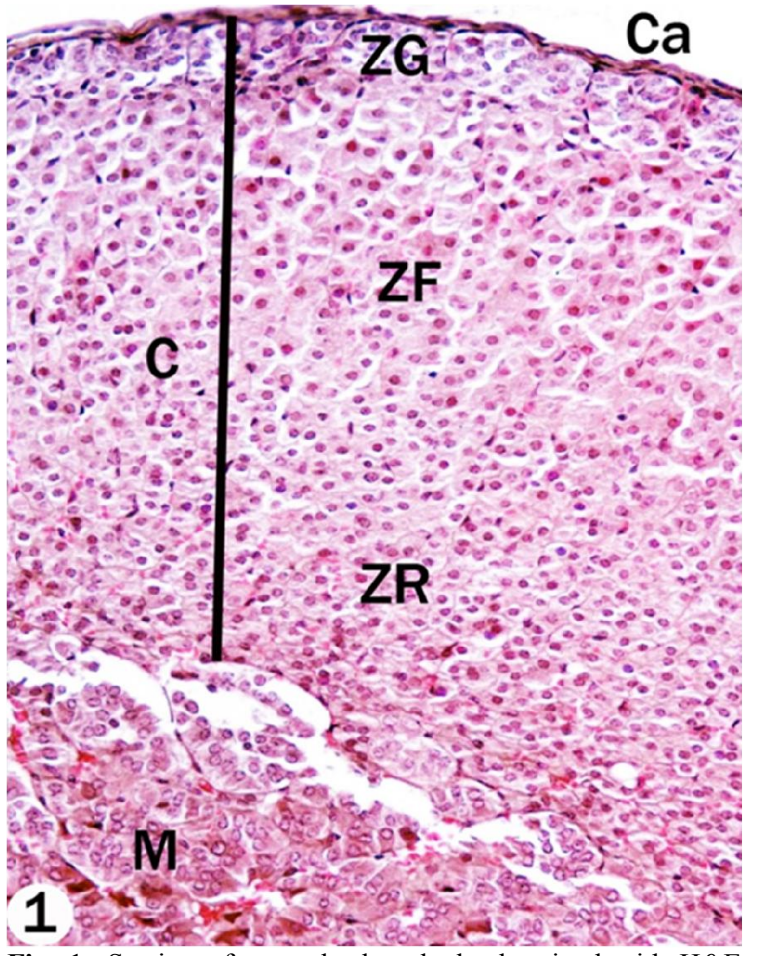

Fig. 1: Section of control adrenal gland stained with $\mathrm{H} \& \mathrm{E}$ showing the capsule (Ca), the cortex (C) which is differentiated into zona glomerulosa $(\mathrm{ZG})$, zona fasciculata $(\mathrm{ZF})$ and zona reticularis (ZR), and the medulla $(\mathrm{M}) . \times 100$

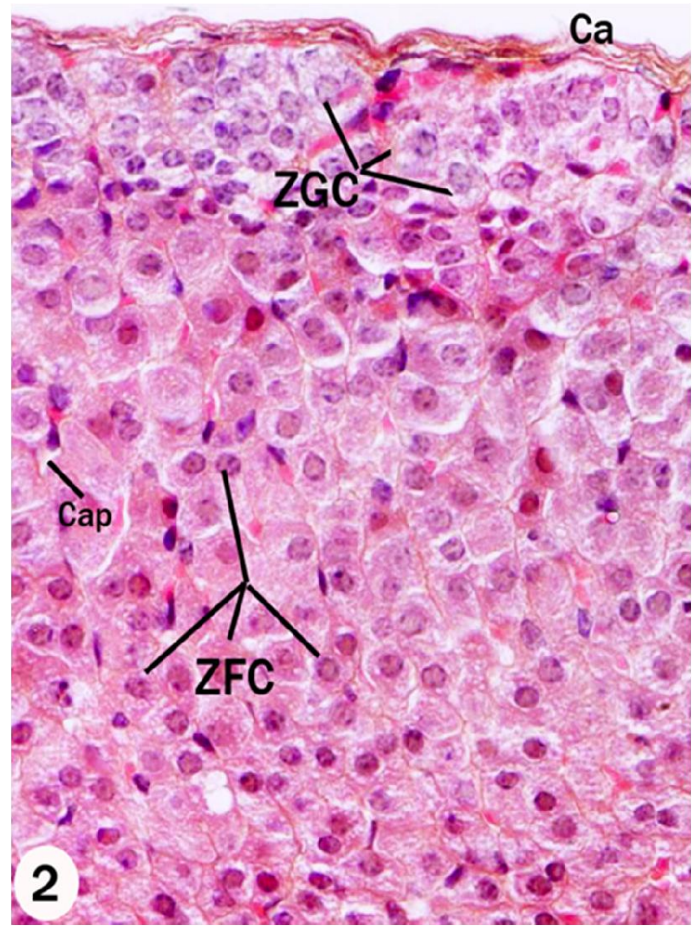

Fig. 2: Section of control adrenal gland stained with $H \& E$ showing the capsule $(\mathrm{Ca})$, zona glomerulosa cell (ZGC) and zona fasciculate cell (ZFC) separated by narrowed blood capillaries (Cap). x 400

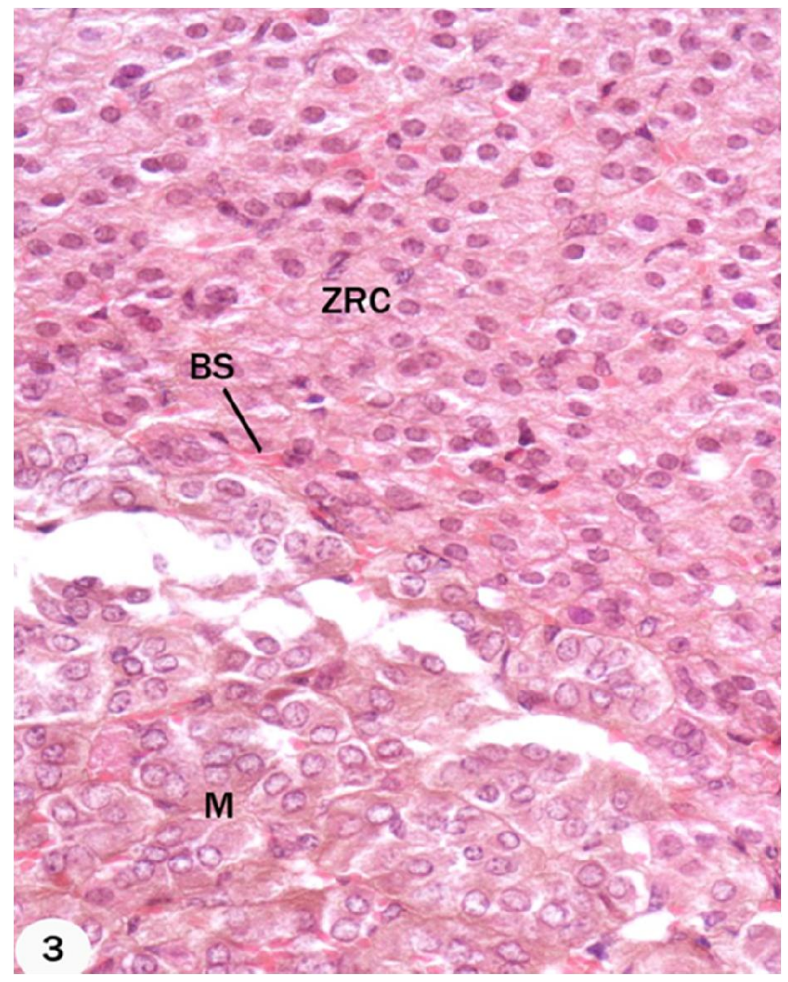

Fig. 3: Section of control adrenal gland stained with $H \& E$ showing zona reticularis cells (ZRC) separated by blood sinusoids (BS). Part of medulla noticed (M). x 400

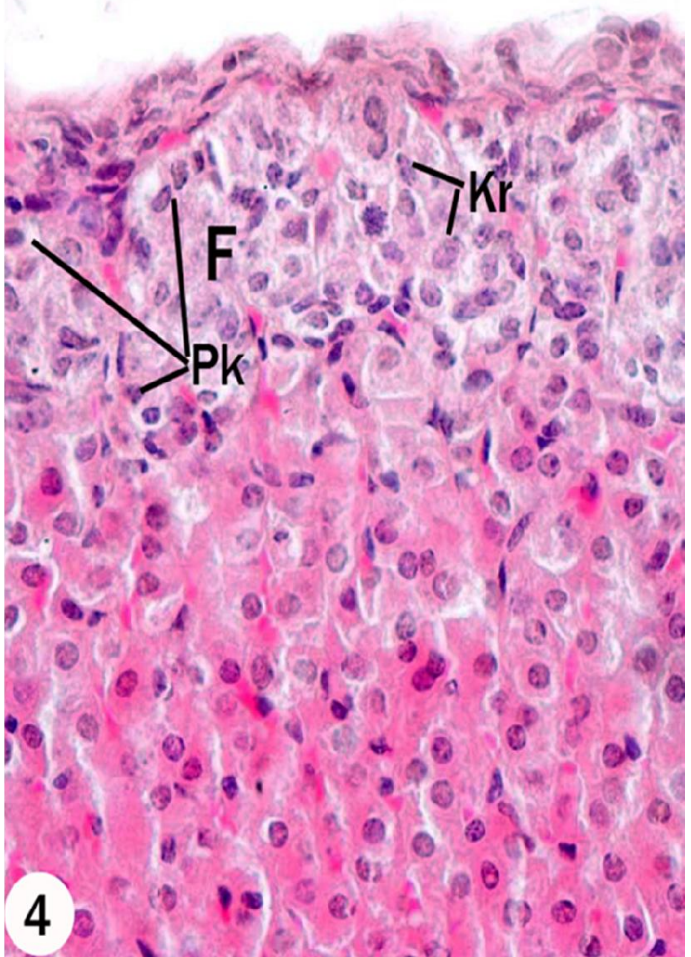

Fig. 4: Section of adrenal gland of mice injected with dexamethasone $(4 \mathrm{mg} / \mathrm{kg} . b w)$ stained with $\mathrm{H} \& \mathrm{E}$. showing fibrotic area $(\mathrm{F})$ in zona glomerulosa, pyknosis $(\mathrm{Pk})$ and karyorrhexis (Kr) nuclei. x 400 


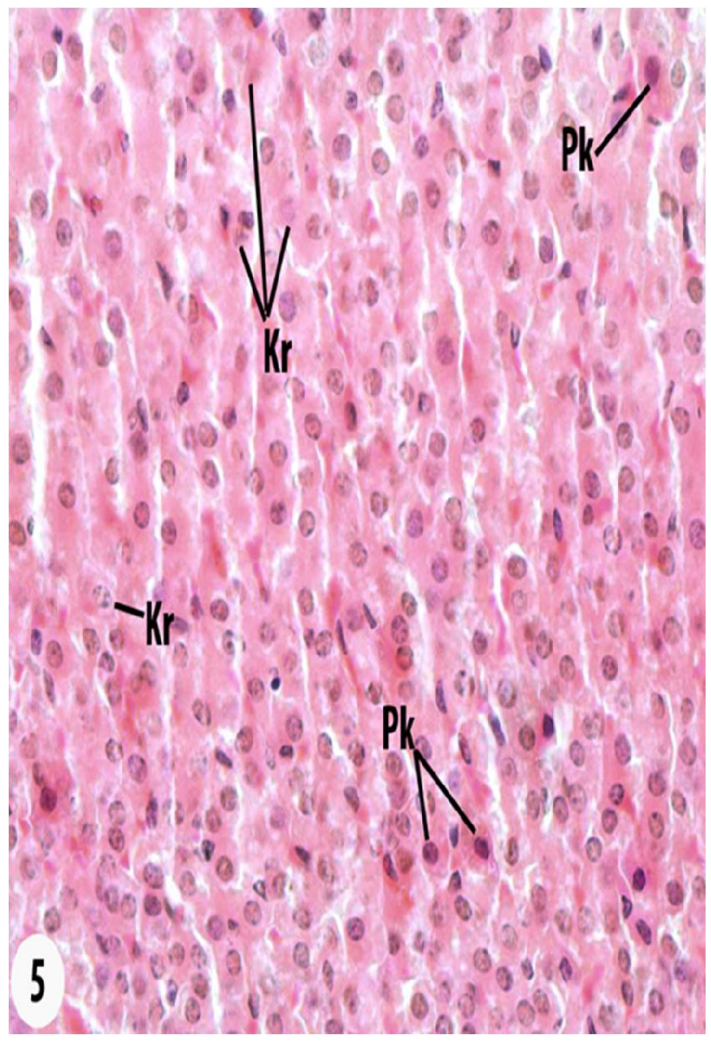

Fig. 5: Section of adrenal gland of mice injected with dexamethasone $(4 \mathrm{mg} / \mathrm{kg} . \mathrm{bw})$ stained with H\&E. showing pyknosis $(\mathrm{Pk})$ and karyorrhexis $(\mathrm{Kr})$ nuclei in zona fasciculata and zona reticularis. x 400

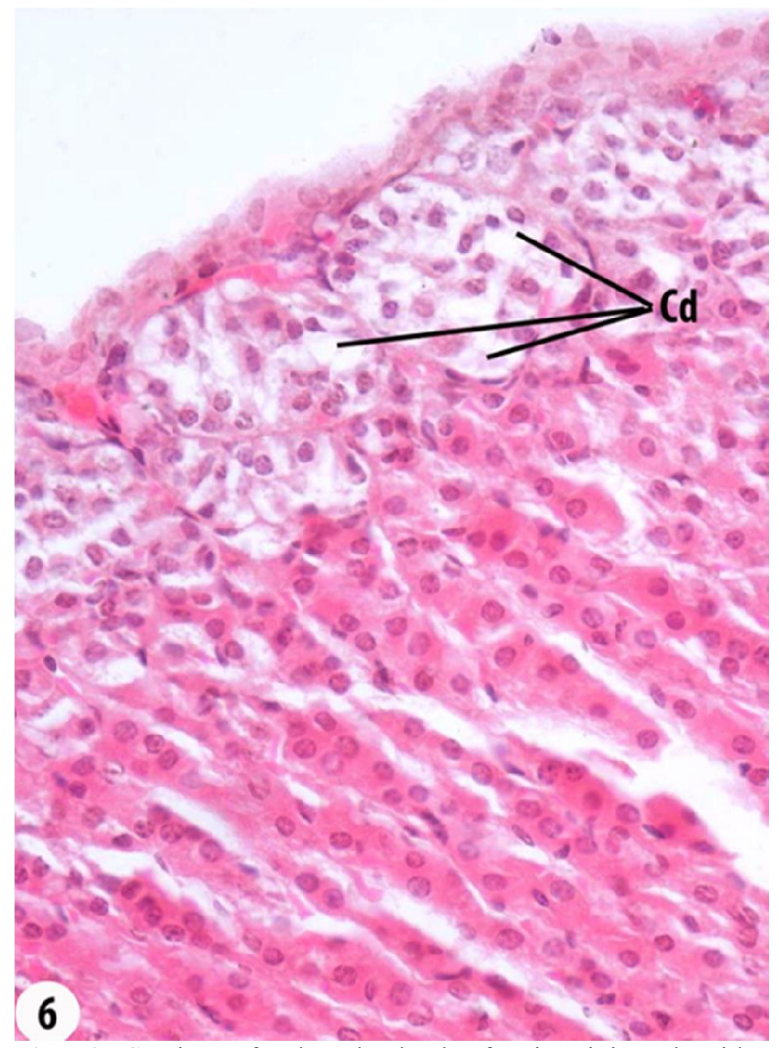

Fig. 6: Section of adrenal gland of mice injected with dexamethasone $(8 \mathrm{mg} / \mathrm{kg} . \mathrm{bw})$ stained with H\&E. showing cytoplasm degeneration of zona glomerulosa cells $(\mathrm{Cd})$. $\mathrm{X}$ 400

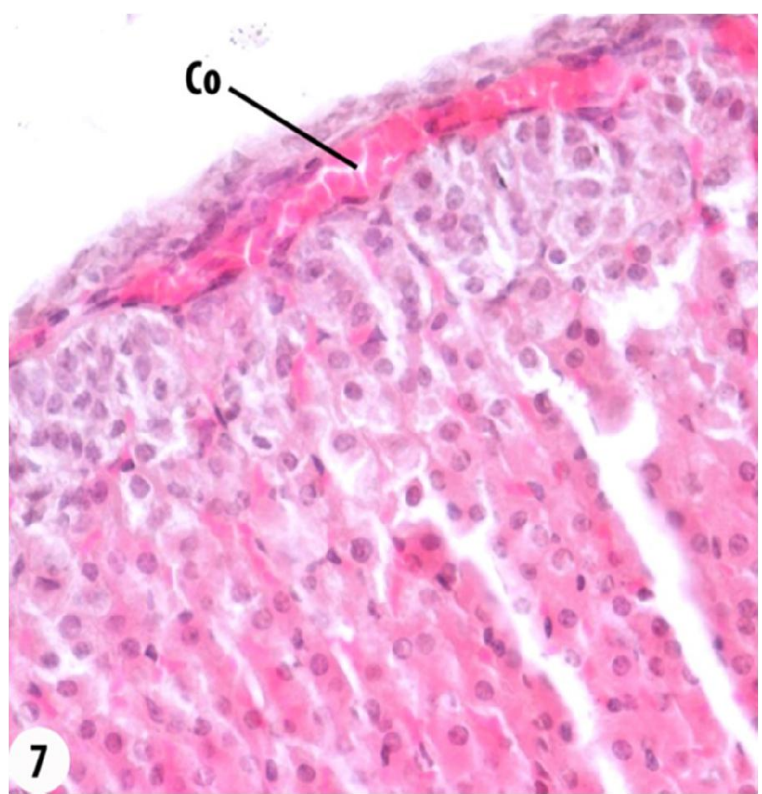

Fig. 7: Section of adrenal gland of mice injected with dexamethasone $(8 \mathrm{mg} / \mathrm{kg} . \mathrm{bw})$ stained with $\mathrm{H} \& \mathrm{E}$. showing dilatation and congestion of blood vessels (Co). x 400

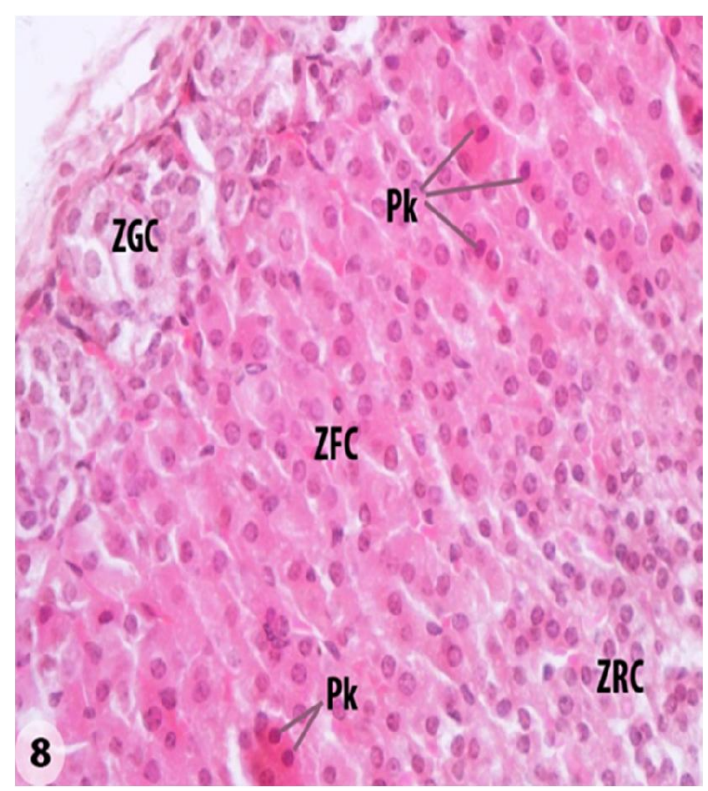

Fig. 8: Section of adrenal gland of mice injected with dexamethasone $(8 \mathrm{mg} / \mathrm{kg} . \mathrm{bw})$ stained with $\mathrm{H} \& \mathrm{E}$. showing pyknosis $(\mathrm{Pk})$ nuclei in zona fasciculata and zona reticularis. x 400 


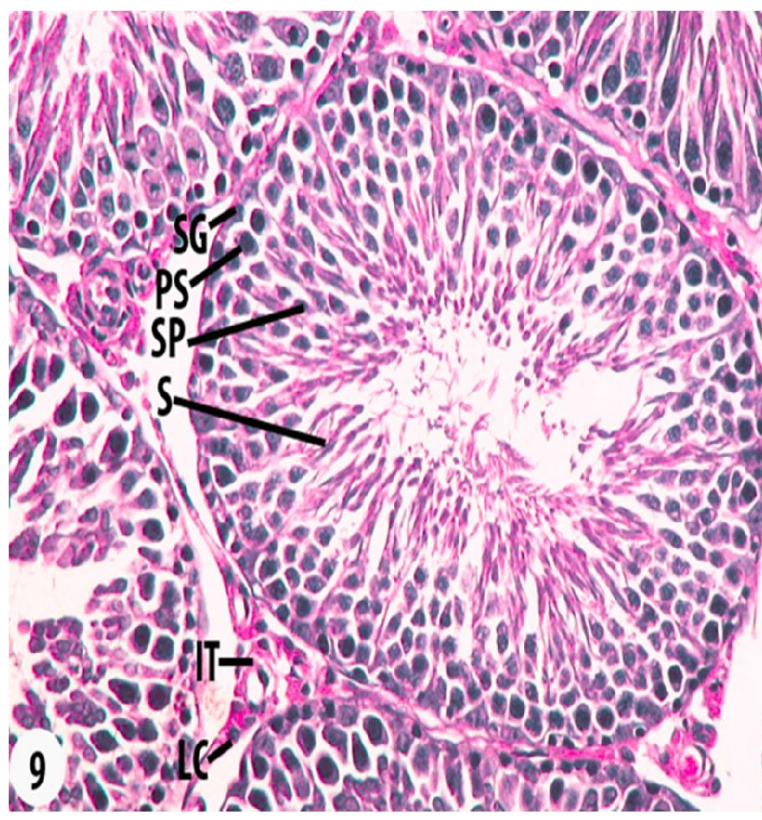

Fig. 9: Normal testicular tissue architecture of control testis revealing, seminiferous tubules with spermatogonia (SG), primary spermatocytes (PS), rounded spermatids (SP) and elongated spermatids $(\mathrm{S})$, in addition to the interstitial tissues (IT) containing Leydig cells (LC). X 200

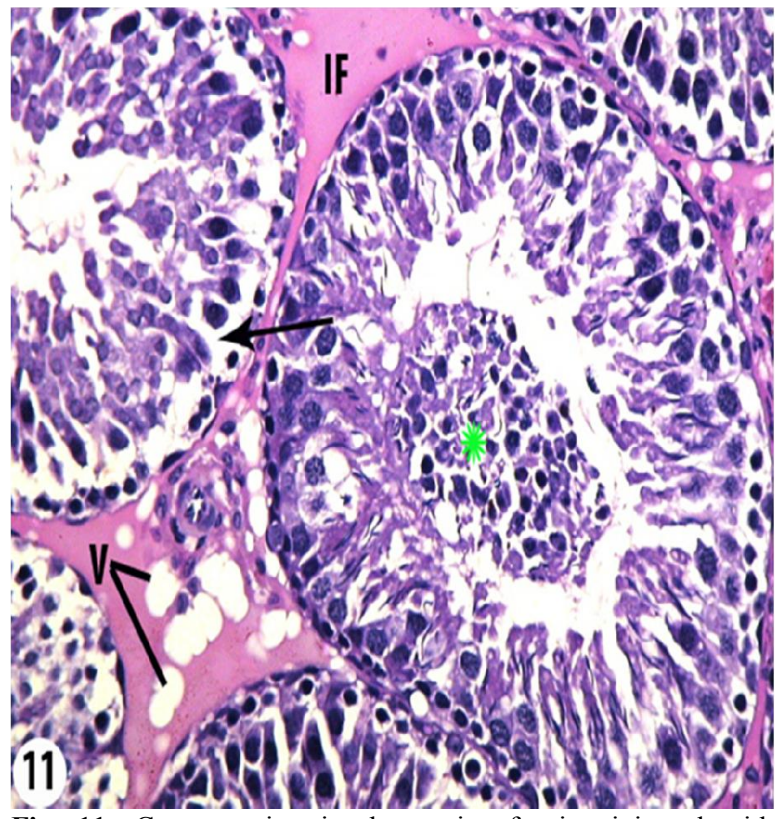

Fig. 11: Cross section in the testis of mice injected with dexamethasone $(8 \mathrm{mg} / \mathrm{kg} . \mathrm{bw})$ stained with H\&E. showing infiltration (If) of the interstitial tissue and vacuoles (v). separeation of spermatogenic cells from the basement membrane in some tubules (arrow), exfoliation of cells in the lumen (star). X 200

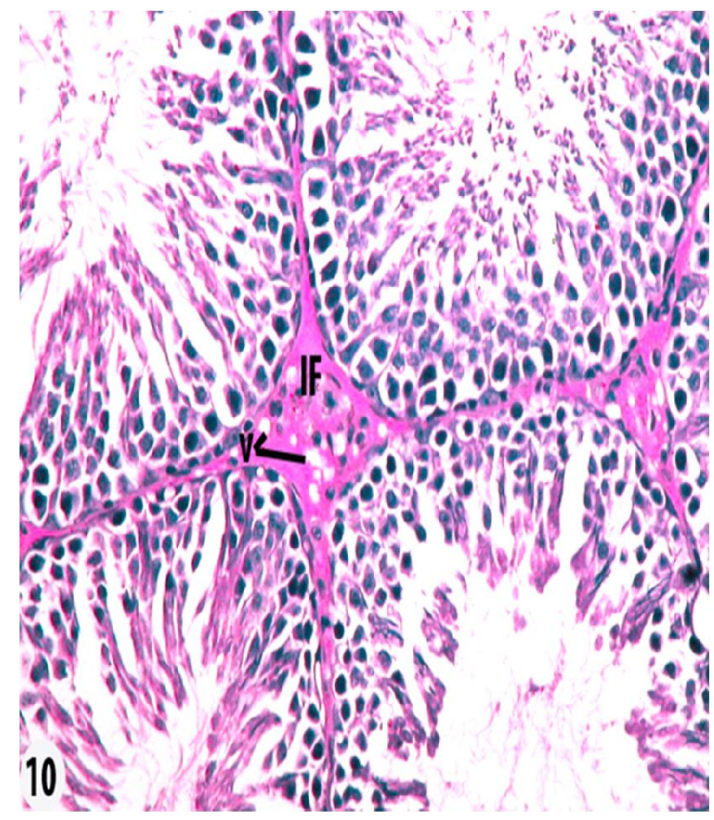

Fig. 10: Cross section in the testis of mice injected with dexamethasone $(4 \mathrm{mg} / \mathrm{kg} . \mathrm{bw})$ stained with H\&E. showing infiltration (If) of the interstitial tissue and vacuoles (v). X 200

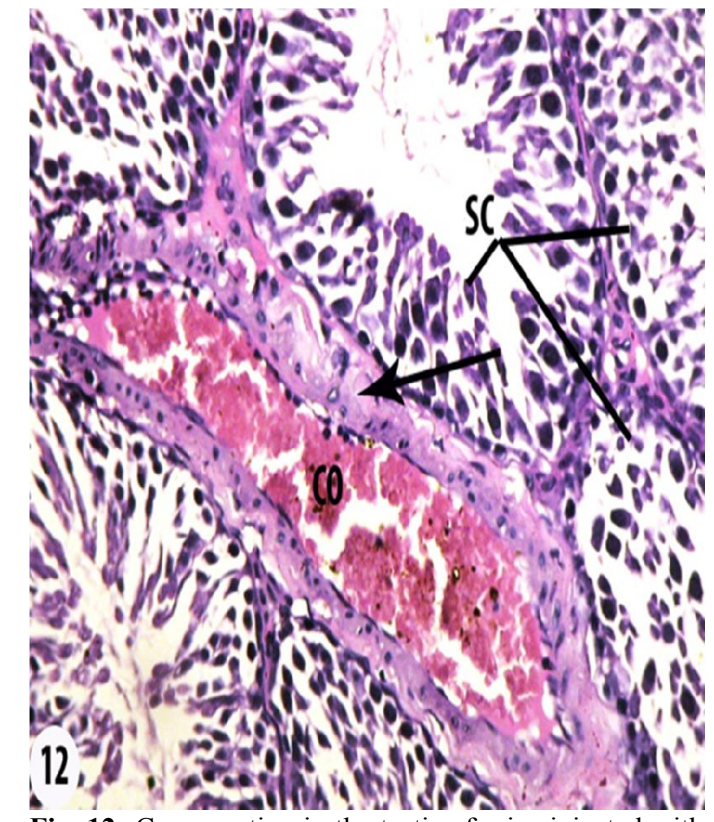

Fig. 12: Cross section in the testis of mice injected with dexamethasone $(8 \mathrm{mg} / \mathrm{kg} . b w)$ stained with H\&E. showing thickening (arrow), dilatation and congestion of blood vessels (Co). Degeneration of spermatogenic cells and pyknotic nuclei (arrows) were noticed. X 200

\section{Discussion}

Changes of the adrenal cortex that resulted in the present study such as cytoplasmic vacuolation, nuclear pyknosis and shrinkage in the thickness of the three cortical zones are in 
accordance with Elshennawy and Abo Elwafa (2011). They confirmed that adrenal cortex of treated rats with hydrocortisone displayed shrinkage in the thickness of its cortical zones, a mass of cortical cells projected out of its thickened capsule, beside zona glomerulosa, fasciculata and reticularis cells are compressed, lost their normal organization, vacuolation and fibrotic areas in the cytoplasm. Coburn-Litvak et al. (2004) found that corticosterone, subcutaneously injected into rats significantly reduced adrenal gland weight. The influence of dexamethasone, a potent synthetic glucocorticoid on the rat's adrenal gland was investigated by different researchers (Almeida et al., 2001; Illera et al., 2007; Silvan et al., 2007; Ye et al., 2008). These studies demonstrated that dexamethasone reduced the adrenal gland weight as a result of the atrophy in the layers of adrenal cortex, causing a suppressive steroid secretion from the adrenal cortical cells.

Dexamethasone causes accumulation of lipid droplets in cells of zona fasciculate and zona reticularis (Almeida et al., 2001). Much of the cholesterol used in steroid synthesis is stored in lipid droplets of the steroid-forming cells. Lipid accumulation inside adrenocortical cells may be considered as a secondary phenomenon due to the inhibition of the sequence of reactions leading from cholesterol to progesterone (Hemmaid, 2009).

The results of the present study revealed various histological alterations of the testicular tissues. Spermatogenic cells lost their normal shapes, possessing features of necrotic cells. As De Rooij and Russell (2000) described, spermatogonia are particularly vulnerable to toxicants and physical agents. In particular, because of their mitotic activity, they are more vulnerable than Sertoli, Leydig cells and spermatids.

Elshennawy and Abo Elwafa (2011) found that hydrocortisone administration into adult male rats exerts a clear effect on testicular structures and ultrastructures including degenerated changes of germ cells, Sertoli cells, and Leydig cells. These changes reflect on their functions exerting deficiency in their performance, also exerts an effect on Leydig cells; showing remarkable decrease in number and size. Close relationship between Leydig cells and blood vessels suggests that these cells are at high risk of exogenous toxicants.

Alterations in Dex-treated mice may relate to induction of apoptosis in testicular germ cells. Additionally, the reduction in seminiferous tubules diameters may have been a consequence of germ cell loss (Khorsandi et al., 2013). Dexamethasone suppresses serum testosterone and luteinizing hormone (LH), which influences testicular endocrine function and also indirectly affects sperm maturation within the epididymis, sperm transport, sperm metabolism (Gur et al., 2005).

These findings were in agreement with previous investigators who observed that chronically elevated glucocorticoids have adverse effects on the reproductive system. Abo-Youssef et al. (2018) found that glucocorticoids affect steroidogenesis, spermatogenesis and cause spermatogenic arrest at a certain level of germ cells. Also, they reported that glucocorticoid receptor has been found on Leydig cells, early pachytene and zygotene primary spermatocytes, peritubular myoid cells, fibroblasts and basal cells of the epididymis. High levels of corticosteroids may be having inhibitory effects on testosterone production from Leydig cell steroidogenesis which appeared to be mediated through inhibition of LH signal transduction (Sankar BR et al., 2000). However, some authors mentioned that cortisol has a direct inhibitory effect on the testicular androgen secretion independent of the LH secretion (Consten D et al., 2002).

Glucocorticoids bring about their multiple effects by activating the intracellular glucocorticoids receptor that binds to specific glucocorticoids-responsive elements in the vicinity of regulated genes and subsequently affect their expression. It is estimated that glucocorticoid receptors can interact as transcription factors for about $30 \%$ of genes, so it is not surprising that glucocorticoids induce a wide range of responses (Wahbah et al., 2010).

\section{References}

Abo-Youssef, A.M., W.Y. Mohammed, and Y.M. Youssef, 2018. Histological Study of the Effect of Administration of Exogenous Glucocorticoids on the Testis of Albino Rats. Egypt. Acad. J. Biol. Sci., 10(1): 1-12.

Almeida, H., S. Ros-Dominguez, N. Ribeiro, M.C. Magalhaes, and M.M. Magalhaes, 2001. Dexamethasone administration during ageing - a structural, and biochemical study on rat adrenal cortex. Biol. Cell, 93: 372-87. 
Coburn-Litvak P.S., D.A. Tata, H.E. Gorby, D.P. Mccloskey, G. Richardson, and B.J., and erson, 2004. Chronic corticosterone affects brain weight,, and mitochondrial, but not glial volume fraction in hippocampal area CA3. Neuroscience, 124: 429-38.

Consten D., J.G. Lambert, H. Komen, and H.J. Goos, 2002. Corticosteroids affect the testicular, and rogen production in male common carp, Cyprinus carpio L.). Biol. Reprod. 66(1):106-111.

De Rooij D.G., and L.D. Russell, 2000. All you wanted to know about spermatogonia but were afraid to ask. J., and rol., 776-798.

Delafield, F., 1984. Haematoxylin, and eosin for general staining. Staining of the animal tissues practical, and theoretical. Oxford University Press, London, UK.

Elshennawy W.W., and H.R. Abo Elwafa, 2011. Histological, and Ultrastructural Changes in Mammalian Testis under the Effect of Hydrocortisone. J. American Science, 7(9):38-48.

Elshennawy W.W., and H.R. Abo Elwafa, 2011. Hydrocortisone impact on the structural, and ultrastructural characteristics of mammalian adrenal cortex. J. of American science, 7(5):1053-1054.

Gevorgyan E.S., Z.V. Yavroyan, A.G. Galstyan, and L.O. Demirkhanyan, 2008. Content of some phospholipid fractions in rat liver nuclei after the in vivo action of hydrocortisone, and insulin. Biophysics, 1: 18-24.

Ghadhban R.F., and A.H. Jawad, 2013. Effects of dexamethasone, estrogen administration on leptin, thyroid, reproductive hormone concentration, and lipid profile of female rabbits serum. Bas.j.vet.Res., 12(1):41-53.

Gloor B., Uhl W., O. Tcholakov, A. Roggo, C.A. Muller, M. Worni, and M.W. Buchler, 2001. Hydrocortisone treatment of early SIRS in acute experimental pancreatitis. Dig. Dis. Sci., 46: 2154-2161.

Gur S., T. Bozkurt, and G. Turk, 2005. Short term effects of dexamethasone on hyaluronidase activity, and sperm characteristics in rams. Animal Reproduction Science 90: 255-263.

Harry R., G. Auzinger, and J. Wendon, 2003. The effects of supraphysiological doses of corticosteroids in hypotensive liver failure. Liver Int., 23: 71-77.

Hemmaid K.Z., 2009. Ultrastructural patterns of the adrenal cortical cells of rats during suppression of secretion by dexamethasone injection. Fourth Environment Conference, Faculty of Science, Zagazig University, 65-83.

Illera J.C., L. Pena, M.M. Martinez-Mateos, L. Camacho, A. Blass, P. Garcia-Partida, M.J. Illera, and G. Silvan, 2007. The effect of long-term exposure to combinations of growth promoters in Long Evans rats. Part 2: adrenal morphology, histopathology, and immunochemical studies). Analytic Chem. Acta, 586: 252-258.

Julia C.B., 2006. Glucocorticoids: exemplars of multi-tasking. Br. J. Pharmacol. 147:258-268.

Khorsandi L., M. Mirhoseini, M. Mohamadpour, M. Orazizadeh, and S. Khaghani, 2013. Effect of curcumin on dexamethasone-induced testicular toxicity in mice. Pharm. Biol., 51(2): 206212.

Kornblith A.B., J.E. Herndon, E. Zuckerman, P.A. Godley, D. Savarese, N.J. Vogelzang, and J.C. Holland, 2001. The impact of docetaxel, estramustine,, and low dose hydrocortisone on the quality of life of men with hormone refractory prostate cancer, and their partners: a feasibility study. Ann. Oncol., 12: 633-41.

Kusuda Y., Y. Kondo, Y. Miyagi, T. Munemasa, Y. Hori, F. Aonuma, S. Tsuka, T. Mukaibo, C. Masaki, and R. Hosokawa, 2019. Long-term dexamethasone treatment diminishes storeoperated $\mathrm{Ca} 2+$ entry in salivary acinar cells International J. Oral Sci. 11(1).

Noel K.I., 2012. Exocrine Pancreas under the Effect of Glucocorticoids: Histological, and Morphometry Study IRAQI J. MED. SCI., 10(3): 213-219.

Piffer R.C., and O.C. Pereira, 2004. Reproductive aspects in female rats exposed prenatally to hydrocortisone. Comp. Biochem. Physiol., 139: 11-16.

Rabee D.A., H.J. Kahiosh, and S.H. Abdulatif, 2014. The effect of different doses from hydrocortisone on the liver tissue in the male rat. Kerbala J. Pharm. Sci., 7: 58-66.

Rodrigues-Mascarenhas S., N. Fernandes dos Santos, and V.M. Rumjanek, 2006. Synergistic effect between ouabain, and glucocorticoids for the induction of thymic atrophy. Biosci Rep., 26: 159-69. 
Sankar B.R., R.R. Maran, S. Sudha, P. Govindarajulu, and K. Balasubramanian, 2000. Chronic corticosterone treatment impairs Leydig cell 11 betahydroxysteroid dehydrogenase activity, and LH-stimulated testosterone production. Horm. Metab. Res., 32(4):142-146.

Silvan G., M.M. Martinez-Mateos, A. Blass, L. Camacho, A. Gonzalez-Gil, P. Garcia Partida, and J.C. Illera, 2007. The effect of long-term exposure to combinations of growth promoters in Long Evans rats. Part 1: Endocrine adrenal function. Anal. Chim. Acta, 586: 246-51.

Tata D.A., and B.J., and erson, 2010. The effects of chronic glucocorticoid exposure on dendritic length synapse numbers, and glial volume in animal models: implications for hippocampal volume reductions in depression. Physiol. Behav., 99: 186-93.

Urbach, V., D. E. Walsh,, B. Mainprice,, J. Bousquet, and B. J. Harvey,, 2002. Rapid nongenomic inhibition of ATP-induced Cl- secretion by dexamethasone in human bronchial epithelium. J. Physiol. 545, 869-878.

Wahbah, N.S., E.A. Abd El- Fattah, F.E. Ahmed, and E. Z. Hassan, 2010. Histological Study of the Effect of Exogenous Glucocorticoids on the Testis of Prepubertal Albino Rat. Egypt. J. Histol., 33(2): 353 - 364 .

Yarushkina, N.I., 2008. The role of hypothalamo-hypophyseal- adrenocortical system hormones in controlling pain sensitivity. Neurosci. Behav. Physiol., 38: 759-766.

Ye P., C.J. Kenyon, S.M. Mackenzie, K. Nichol, J.R. Seckl, R. Fraser, J.M. Connell, and E. Davies, 2008. Effects of ACTH, dexamethasone, and adrenalectomy on $11 \beta$-hydroxylase, CYP11B1), and aldosterone synthase, CYP11B2) gene expression in the rat central nervous system. J. Endocrinol., 196: 305-11. 